African Crop Science Journal by African Crop Science Society is licensed under a Creative Commons Attribution 3.0 Uganda License. Based on a work at www.ajol.info/ and www.bioline.org.br/cs

DOI: https://dx.doi.org/10.4314/acsj.v28i1.13S

\title{
INFLUENCE OF TRANSACTION COSTS ON CHOICE OF MARKETING OUTLETS AMONG SMALLHOLDER PEACH FARMERS IN LESOTHO
}

\author{
L.P. RAFONEKE, P.M. MSHENGA ${ }^{1}$, G. OWUOR ${ }^{2}$ and A.M. RANTLO ${ }^{3}$ \\ Department of Agricultural Economics and Agibusiness Management, Egerton University, \\ P. O. Box 536, Njoro, Kenya \\ ${ }^{1}$ Department of Agricultural Economics and Agibusiness Management, Egerton University, \\ P. O. Box 536, Njoro, Kenya \\ ${ }^{2}$ Department of Agricultural Economics and Agibusiness Management, Egerton University, \\ P. O. Box 536, Njoro, Kenya \\ ${ }^{3}$ Department of Agricultural Economics and Extension, National University of Lesotho, \\ P. O. Box 180, Roma, Lesotho \\ Corresponding author: dintlerafoneke1990@gmail.com
}

\begin{abstract}
Peach (Prunus persica) production is a major agro-economic activity in Lesotho. However, most smallholder peach farmers in Lesotho still fail to reap the benefits that are in line with peach commercialization. This is because of high transaction costs, which vary along with different peach marketing outlets. This study was conducted to determine the influence of transaction costs on the choice of marketing outlets of peaches in Lesotho. A multistage sampling technique was used to select 90 respondents for this study. Cross-sectional data were collected using a semi-structured questionnaire. A Multivariate probit model was used to analyse transaction costs influencing the choice of marketing outlets among smallholder peach farmers. The study revealed that gender and communication costs positively influenced the choice of farm gate; while the time taken to reach other outlets and average monthly income negatively influenced the choice of farm gate outlets. Sorting, grading and communication costs negatively impacted the local market; whereas, the average monthly income positively influenced it. Household size influenced farmers' export market choice negatively. Evidence from the results suggests that the improvement of roads and communication infrastructure could enhance farmers' income through the proper selection of marketing outlets. Access to market information regarding both distance and the time taken to reach each of the outlets should also be improved.
\end{abstract}

Key Words: Farm gate, multivariate probit, Prunus persica

\section{RÉSUMÉ}

La production de pêche (Prunus persica) est une activité agro-économique majeure au Lesotho. Cependant, la plupart des petits exploitants de pêches au Lesotho ne parviennent toujours pas à 
récolter les avantages qui sont en ligne avec la commercialisation des pêches. Cela est dû aux coûts de transaction élevés, qui varient en fonction des différents points de vente de pêche. Cette étude a été menée pour déterminer l'influence des coûts de transaction sur le choix des débouchés commerciaux des pêches au Lesotho. Une technique d'échantillonnage à plusieurs degrés a été utilisée pour sélectionner 90 répondants pour cette étude. Les données transversales ont été collectées à l'aide d'un questionnaire semi-structuré. Un modèle probit multivarié a ensuite été utilisé pour analyser les coûts de transaction influençant le choix des débouchés commerciaux parmi les petits exploitants de pêches. L'étude a révélé que le sexe et les coûts de communication ont eu une influence positive sur le choix de la ferme; tandis que le temps nécessaire pour atteindre d'autres points de vente et le revenu mensuel moyen ont influencé négativement le choix du point de vente à la ferme. Tri, classement et les coûts de communication ont eu un impact négatif sur le marché local; tandis que le revenu mensuel moyen l'a influencé positivement. La taille des ménages a influencé négativement le choix du marché d'exportation des agriculteurs. Les résultats des résultats suggèrent que l'amélioration des routes et des infrastructures de communication pourrait améliorer les revenus des agriculteurs grâce à une sélection appropriée des débouchés commerciaux. L'accès aux informations du marché concernant à la fois la distance et le temps nécessaire pour atteindre chacun des points de vente devrait également être amélioré.

Mots Clés: Ferme, probit multivarié, Prunus persica

\section{INTRODUCTION}

Peach (Prunus persica) is a crop of growing importance in southern Africa, particularly in Lesotho. Its production was rated at approximately 23,000 metric tonnes in the year 2017/18 (World Food Programme (WFP), 2017). In Lesotho, the production of peaches dates to early 1800 upon the arrival of the missionaries. The peach sector has reportedly contributed approximately $43.77 \%$, equivalent to US\$ 71, 429 to the total gross value of all deciduous fruits (US\$ 285, 714 ) in Lesotho (World Food Programme(WFP), 2017). According to Sekoai and Rantlo (2016); most of the smallholder peach farmers generate income through sales of dried peaches in both domestic and foreign (South African) markets. The other farmers, as well as farmers' associations were earlier reported to sell both processed and unprocessed peaches in informal and formal markets (FAO, 2014). Thus, Lesotho is one of the developing countries that still perform marketing functions traditionally.

Majority of smallholder peach farmers in the country are located in remote areas, with poor infrastructure. As a result, they often fail to participate in markets due to high transportation costs and lack of guaranteed markets (Rafoneke and Rantlo, 2016; Sekoai and Rantlo, 2016). High transaction costs restrict the potential gains from current opportunities that are in line with commercialisation of peaches in the country. Moreover, marketing plays a significant role in transforming smallholder farmers into commercial producers as the availability of markets serves as an incentive for farmers to increase their scale of production. The issue of how farmers select marketing outlets, in light of transaction costs, has received little attention in Lesotho. It is through identification of marketing outlets that policy makers can get useful information for formulating marketing policies which are of benefit to smallholder peach farmers and the entire peach fruit value chain in Lesotho.

Owing to the nature of African farming communities, most farming activities take place in remote rural areas where smallholder peach farmers often fail to sell in high value markets due to high transaction costs and limited market options (Key, 2000; Jagwe, 2011; Okoye et al., 2016). The objective of 
this study was to determine the influence of transaction costs on the choice of marketing outlets among the smallholder peach farmers in Lesotho.

\section{METHODOLOGY}

Study area. This study was conducted from July to August 2019 in Leribe district, one of the ten districts of Lesotho. The district covers an area of $2,828 \mathrm{Km}^{2}$, between longitude $28^{\circ}$ $53^{\prime} 0^{\prime \prime}$ South and latitude $28^{\circ} 3^{\prime} 0^{\prime \prime}$ East (Moeletsi and Walker, 2013). Leribe District is made up of three agro-ecological zones; lowlands (42\%), highlands (30\%) and foothills (28\%) (LGNSP, 2009). The district has thirteen constituencies, out of which five were selected for the study.

Sample selection. A survey was conducted using a semi-structured questionnaire. Reliability and validity of the data collection tool were tested by test-retest correlation and construct validity method, respectively. Consequently, the errors were corrected before using it in the final data collection. A multistage sampling technique was used to select five constituencies (Pela-Tsoeu, Leribe, Hlotse, Tsikoane, and Kolonyama), from which the study sample was drawn. A list of all farmers in the selected constituencies was obtained from the Department of Horticulture in the Ministry of Agriculture and Food Security. Out of the peach farmers' list, only 90 semi-commercial peach producers who had 60-150 peach trees in their farms were selected for the study. Data on both qualitative and quantitative attributes, marketing costs and other market-related prices, as well as marketing outlets were collected.

Econometric model. To determine the influence of transaction cost factors on the choice of marketing outlets, a multivariate probit model was used. The model was chosen since the dependent variable was discrete with three levels (farm gate, local and export market outlets), and only farmers' choice on a particular outlet was observed. Hence, the latent univariate logit model for choice of each outlet was specified as described by Greene (2012) and Adugna et al. (2019).

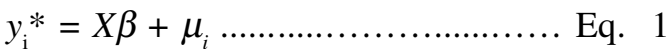

$$
\begin{aligned}
& y_{\mathrm{i}}=\left\{1 \text { if } y_{\mathrm{i}}{ }^{*}=X \beta+\mu_{i}>0 \text {; } 0 \text { if } y_{\mathrm{i}}{ }^{*} \leq 0\right\}
\end{aligned}
$$

Where:

$y_{\mathrm{i}}^{*}$ was a binary latent (unobserved variable) for marketing outlet choice which was observed when $y_{i}^{*}>1,0$ otherwise; $X$ was regarded as a vector of transaction costs influencing peach farmers' choice on the marketing outlets.

However, since peach farmers choose one or more market outlets at the same time, they get subjected to the anticipated benefits and risks correlated with each marketing outlet (Adugna et al., 2019). The multivariate probit model allows for free correlation between the error terms, while making it possible to simultaneously frame the impact of a ray of predictor variables on each of the different marketing outlet choices (Mokhtarian and Tang, 2011; Arinloye et al., 2012). Since in practice, scientists and researchers often deal with multiple correlated multinomial decisions consisting of two or more possible choices (Bel and Paap, 2014), the multivariate probit model was employed to estimate M-equation probit models, by the method of maximum simulated likelihood (Cappellari and Jenkins, 2003). Hence, this reduced the biasness as a result of correlation between the choices (Train, 2009; Washington et al., 2020).

In this study, the marketing outlet choice was regarded as a system of multiple-choice equation respective to each type of marketing outlet, as outlined in Adugna et al. (2019). The marketing outlets at the disposal of farmers were presumed to be farm gate, local market 
and export market, which were econometrically expressed as:

Farmgate $_{i}^{*}=X_{1} \beta_{1}+\varepsilon_{1 i}$ Eq. 3

Localmarket $_{i}^{*}=X_{2} \beta_{2}+\varepsilon_{2 \mathrm{i}}$ Eq. 4

Exporter $_{i}^{*}=X_{3} \beta_{3}+\varepsilon_{3 \mathrm{i}}$ Eq. 5

The multivariate probit approach was used to estimate several correlated binary outcomes jointly. Generally, the multivariate logit model is expressed as:

$y_{\mathrm{im}}=\beta_{\mathrm{im}} X_{\mathrm{im}}+\varepsilon_{\mathrm{im}}$ Eq. 6

Where:

$y_{\text {im }}$ with $(m=1 \ldots k)=$ dependent variable of peach market outlet selected by $i^{\text {th }}$ farmer (The variable was of polychotomous in nature). $X_{\text {im }}$ is $1 \times k$ matrix reflecting independent variables that affect marketing outlet choice; $\beta_{\text {im }}$ is $k \times 1$ vector of unknown parameters to be estimated and $\varepsilon_{\text {im }}, \mathrm{m}=1$...m were error terms distributed as multivariate normal, each with a mean of zero and Covariance $V$, with values of one in the leading diagonal and correlation.

Hence this became a system of equations 7-9:

$y_{1 \mathrm{i}}^{*}=X_{1} \beta_{1}+\varepsilon_{1 \mathrm{i}}$ Eq. 7

$y_{2 \mathrm{i}}^{*}=X_{2} \beta_{2}+\varepsilon_{2 i}$ Eq. 8

$y_{3 \mathrm{i}}^{*}=X_{3} \beta_{3}+\varepsilon_{3 i}$ Eq. 9

The dependent variable was observed through the decision to participate in marketing of peaches or not, such that:

$y_{i m}=\left\{\begin{array}{l}1 \\ 0\end{array}\right.$ if $y_{k}^{*}>0 \quad k=1,2,3$, otherwise

Multicollinearity test was conducted on the predator variable to detect the problem of correlation between explanatory variables. The presence of multicollinearity leads to inflated standard errors and hinders the potential of significance in predictor variables (Akinwande et al., 2015). The Variable Inflation Factor (VIF) was computed on the variables to be used in the model to check for the presence of correlation. A weak correlation between the variables was detected and confirmed by VIF value of less than ten (Yoo et al., 2014).

Breusch-Pagan/Cook-Weisberg test for heteroscedasticity was also conducted. The test results showed the Prob $>\mathrm{Chi}^{2}=0.0000$ for OLS model, which indicated the presence of heteroscedasticity. Therefore, the study rejected the null hypothesis at both 90 and $95 \%$ significance level, and concluded that residuals were not homogeneous. Due to the nonhomogeneity of residuals, the Robust Standard Errors (RSE) were used to deal with the problem of heteroscedasticity (Stock and Watson, 2008).

Specification and description of variable. From Table 1, farm size, gender, age, education level, household size and income level of farmers were variables adopted from Osebeyo and Aye (2014), expected to have a positive influence on the farmers' choice of peach marketing outlet. Farm size (Fsize), was expected to have a positive influence on farmers' decision to sell at farm gate, partnering with middlemen or exporting. Gender (coded as gender) was captured as a dummy, which was measured by assigning one (1) for a male farmer, and zero ( 0 ) for a female. Gender was expected to influence the market outlet choice positively or negatively; different gender negotiates differently in different markets.

Age (coded as age) of the farmers was captured as a continuous variable. Therefore, it was expected that older farmers had more experience gained over years, hence a farmer may decide to sell to traders or export a product based on the profits each outlet offered. Household size (Hsize), was captured as a 
TABLE 1. Description of variables used in the econometric model

\begin{tabular}{|c|c|c|c|c|}
\hline \multirow[t]{2}{*}{ Code } & \multirow[t]{2}{*}{ Measurement } & \multicolumn{3}{|c|}{ Expected signs } \\
\hline & & FG & $\mathrm{LM}$ & Exp \\
\hline
\end{tabular}

\section{Dependent variable}

MrkOutChc 1 if Farm gate (FG)

2 if Local market (LM)

3 if Exporter (Exp)

\section{Independent variables}

Fsize Number of hectares per farm land

Gender Dummy (1=Male, $0=$ Female)

Age Continuous (Years)

Hsize Continuous (number of heads/family)

Incom Average monthly income earned in maloti (M)

Negtxn Hours spend negotiating price, volume and gardens

$\mathrm{Tm}_{\mathrm{R}}$ outlets Time taken in hours to reach other outlets

LfCArr Money paid on arranging contracts

VolLos $\quad \mathrm{kg}$ lost due to spoilage while selling in other outlets

ComCst Amount of airtime spend on the communication

SrtGrdC Money paid per head/g

$\begin{array}{lll}+ & + & + \\ + & + & + \\ + & + & + \\ + & + & + \\ + & + & + \\ + & - & - \\ + & - & - \\ + & +/- & +/- \\ + & - & - \\ + & - & - \\ + & - & -\end{array}$

continuous variable; indicating the number of heads per household. In this way, the outcome was that the family with more heads was more likely to sell in the local market, since the members could help in carrying the peaches to the market. Likewise, families with high level of income (Incom), were expected to sell in almost all of the market outlets, as income served as investment incentive in this study.

Negotiation (Negtxn), was captured by the number of hours a farmer spent negotiating on selling price, quality and quantity. It was, therefore, anticipated to affect the marketing decision either negatively or positively (Maina, 2015). Time taken to reach outlets ( Tim $_{R}$ outlts) was captured as a continuous variable in terms of hours taken to reach marketing outlets from the farm gate. Hence, was expected to have influenced the choice of farm gate positively and the choice of both local and export markets negatively. Legal fees for contractual arrangements (LfCArr), on the other hand, was recorded as the amount of money paid to arrange contracts between farmers and agents. Since contract arrangement guarantees the farmers a ready market, it was expected to positively influence the market outlet choice (Sigei et al., 2014).

The volume of peaches lost due to spoilage and theft (VolLos) was captured as the number of kilogrammes lost during selling season and was expected to have a negative influence on the choice of market outlet (Wosene et al., 2018). Communication costs (ComCst), was recorded as the amount of money spent on communication and advertisement per month. It was expected to affect the choice either positively or negatively. Costs for sorting and grading (SrtGrdCst) adopted from Ogada et al., 2018, was captured in monetary terms and expected to influence farm gate choice 
positively, and negatively influence choices of other market outlets.

\section{RESULTS AND DISCUSSION}

Results of the multivariate analysis are presented in Table 2. The expected multivariate interdependence of selecting marketing outlets; namely, farm gate, local market and export market showed the likelihood ratio test (Rhovalues), of $p_{21}=p_{31}=p_{32}=0$ which was statistically significant at $P<10 \%$. As such, the null hypothesis, which postulated that all $\mathrm{p}$ (Rho) values were jointly equal to 0 ; was rejected, implying the goodness-of-fit of the model and indicating that the decisions on the choice of market outlets were interdependent.

Table 2 shows that gender, time taken to reach other market outlets, average monthly income and communication costs were significant for choice of the farm gate market outlet $(\mathrm{P}<0 \%)$. At the local market outlet, sorting and grading costs, average monthly income and communication costs were also significant; while household size had influence on the choice of export market outlet $(\mathrm{P}<5 \%)$. Some these variables (gender, household size, average monthly income, communication, sorting and grading costs) were in line with economic hypotheses stated previously under the variable description section, while others were not.

Gender had a significant $(\mathrm{P}<0.01)$ positive effect on the choice of selling at farm gate only. Ceteris paribus, being a male farmer increased the chance of selling at

farm gate by $79 \%$, reflecting that male farmers were more likely to sell their produce at farm gate. This finding also indicates some capital disparities in terms of farm land ownership between the male and female peach farmers since farm gate sellers sold in larger quantities as observed in the study of Abu et al. (2016).

Household size had a significant $(\mathrm{P}<0.05)$, but negative impact with respect to the choice of the export market outlet (Table 2). All things equal, a one-member increase in household size generally reduced the probability that a household would choose export market by 13.1 per cent. The result implies that farmers with large household sizes were less likely to sell produce in export market, due to high consumption levels, which are attributed to low marketable surplus to meet high value market outlet demand such as export market outlet demand.

Time taken to reach other outlets was found to have a significant negative influence on choice of farm gate market outlet $(\mathrm{P}<0.05)$ (Table 2). Holding all things constant, this finding indicates that a minute increase in the time taken to reach other market outlets reduces the likelihood of choosing farm gate by $1.4 \%$. This is probably because most of the consumers in Lesotho reside in semi-urban and urban areas, where there is high demand for peaches since most dwellers do not own land to produce the crop. Furthermore, high peach prices give a farmer an incentive to choose other outlets, regardless of transportation costs that are in line with longer travel times (Vorley and Lançon, 2016; Jebesa, 2019). This implies that, longer distance did not override farmers' motives for choosing local and export marketing outlets due to high market prices and high access to market, and price information that are associated with market outlets (Abu et al., 2016). This findingis in agreement with other studies (Fafchamps and Hill, 2005; Hill and Vigneri, 2014; Mugisha et al., 2016), which found out that farmers' access to information, as well as low transportation costs, relative to market outlet prices, may lower the chances of farmers selling at farm gate.

The average monthly income negatively impacted the choice of farm gate outlet (Table 2). A single US dollar increase in average monthly income decreased the chances of choosing farm gate outlet by $0.03 \%$. The finding implies that higher incomes decreased the likelihood of the farmers selling at farm gate. On contrary, the average monthly income positively impacted the choice of local market 
TABLE 2. Multivariate probit results on transaction cost factors influencing choice of marketing outlets

\begin{tabular}{|c|c|c|c|c|c|c|}
\hline \multirow[t]{2}{*}{ Variables } & \multicolumn{2}{|c|}{ Farm gate } & \multicolumn{2}{|c|}{ Local market } & \multicolumn{2}{|c|}{ Export market } \\
\hline & $\beta$ & RSE & $\beta$ & RSE & $\beta$ & RSE \\
\hline Gender of household head & $.791 * * *$ & .422 & .23 & .349 & -.102 & .339 \\
\hline Household size & .018 & .068 & .096 & .067 & $-.131 * *$ & .055 \\
\hline Age in years of respondents & -.036 & .026 & -.020 & .0178 & .011 & .016 \\
\hline Farm size (hectares) & .064 & .123 & -.101 & .142 & -.119 & .141 \\
\hline Time taken to reach other outlets (Min) & $-.014 * *$ & .007 & .005 & .010 & .001 & .008 \\
\hline Log yield loss via spoilage $\left(\mathrm{M} \mathrm{kg}^{-1}\right)$ & 3.88 & 12.4 & 17.6 & 16.2 & -.870 & 15.02 \\
\hline Sorting and grading costs $(\mathrm{M})$ & .0004 & .001 & $-.006^{*}$ & .002 & .001 & .001 \\
\hline Average Monthly income (M) & $-.0003^{*}$ & .0001 & $.0002 * * *$ & .0001 & .00001 & .0001 \\
\hline Communication Costs (M) & $.005^{*}$ & .002 & $-.010^{*}$ & .002 & -.0004 & .002 \\
\hline Negotiating (hours) & -.039 & .067 & -.036 & .048 & -.025 & .029 \\
\hline Contractual arrangement fees (M) & .004 & .004 & .003 & .006 & .001 & .004 \\
\hline Constant & -3.63 & 12.5 & -17.13 & 16.4 & 2.48 & 15.2 \\
\hline Number of observations & & & & & 90 & \\
\hline Log likelihood & & & & & -91.03 & \\
\hline Wald $\chi^{2}(30)$ & & & & & 110.75 & \\
\hline Prob $>\chi^{2}$ & & & & & $0.0000 * * *$ & \\
\hline Likelihood ratio test of & & & & & $\mathrm{p}_{21}=\mathrm{p}_{31}=\mathrm{p}_{32}=0$ & \\
\hline
\end{tabular}


outlet. Ceteris paribus, an additional dollar increase in average monthly income increased the likelihood of selling in local market outlets by $0.02 \%$. These findings suggest that higher incomes increased the likelihood of selling to local markets due to capacity to pay for transportation costs, owning other marketing assets such as mobile phones for accessing market information (Okello, 2019).

The cost of sorting and grading peaches had a significant $(\mathrm{P}<0.1)$ negative effect on the choice of local market outlet only (Table 2). One-dollar increase in the cost of sorting and grading resulted in reduced chances of selling in local markets by $0.6 \%$. This suggests that the higher the sorting and/or grading costs of peaches incurred, the less likely the farmers chose to sell their produce in the local market. The implication is that sorting and grading costs are of less importance in influencing farmer's decision to choose a local market outlet as the costs would easily be transferred to the buyers (Fafchamps and Hill, 2005). This is probably because there was a slight diminutive difference between local market outlets and farm gates, especially to those farms situated along the roads, hence, an indication that the local market was just as informal as farm gate. High transaction costs. sorting and/or grading costs in this case, associated with any outlet normally restricts market penetration among smallholder farmers. Farmers who supposedly had expertise in sorting and grading usually preferred selling their produce in the high value markets such as export market, in order to cover costs associated with acquiring the expertise (Jari and Fraser, 2009).

Communication costs were found to positively influence the choice of farm gate at $(\mathrm{P}<0.1)$ (Table 2). Ceteris paribus, one-dollar increase in the cost of communication increased the likelihood of choosing farm gate by $0.5 \%$.This implies that high communication costs increase the likelihood of selling peaches at farm gate due low infrastructure in most of rural settings of Lesotho, which in turn favours face-to-face interactions for effective communication.

Table 2 shows that communication costs negatively influenced the choice of local market outlets. Ceteris paribus, one-dollar increase in the cost of communication decreased the likelihood of choosing local market outlet by $1 \%$. The implication from the findings is that farmers who incurred higher communication costs were less likely to sell in local market. This is because farmers who sold at farm gate normally knewn potential buyers who were possibly contacted during the time of peach sale.

Hamilton et al. (2013) noted that the cost incurred on advertisement, communication in this case, could increase the sales rate thus reducing the loss that can accrue to spoilage of the produce. Our finding is in line with Melese et al. (2018), who reported that communication is used to access information and knowledge which strengthen production and marketing. On the contrary, the negative effect between communication costs and local market outlet choice could be due to proximity of a farm to the market, which is also within vicinity of the buyers and eases communication through word of mouth between farmers and buyers thereby increasingpeach sale at relatively low advertisement costs. Information spreading by word of mouth is equally important in the flow of information (Lancaster and Torres, 2019).

\section{CONCLUSION}

The study reveals that choice of farm gate market outlet is positively influenced by gender of the respondents and communication; while time taken to reach other outlets and average monthly income costs negatively influenced farmers' decision with regard to choice of farm gate outlet. Three variables; sorting and grading costs, average monthly income and communication costs determined local market outlet decision; while household size 
influenced farmers' export market negatively. Improving roads and communication infrastructure could enhance marketing of peaches at all outlets. Access to market information regarding both distance and time taken to reach each of the outlets can help in reducing transaction costs as farmers would be marking more informed decisions regarding sale of their products.

\section{ACKNOWLEDGEMENT}

To African Economic Research Consortium (AERC), through the Collaborative Masters of Science in Agricultural and Applied Economics (CMAAE) Secretariat for the award of the scholarship which enabled the first author to pursue a Masters Degree in Agricultural and Applied Economics at Egerton University and for training in Agricultural and Policy Analysis in the University of Pretoria, South Africa, as well as funding the survey underlying this study. The authors are grateful to the Mastercard Foundation and Regional Universities Forum for Capacity Building in Agriculture (RUFORUM) for funding research and publication cost through the Transforming African Agricultural Universities to meaningfully contribute to Africa's growth and development (TAGDev) Program.

\section{REFERENCES}

Abu, B.M., Issahaku, H. and Nkegbe, P.K. 2016. Farmgate versus market centre sales: A multi-crop approach. Agricultural and Food Economics 4(1):21.

Adugna, M., Ketema, M., Goshu, D. and Debebe, S. 2019. Market outlet choice decision and its effect on income and productivity of smallholder vegetable producers in Lake Tanabasin, Ethiopia. Review of Agricultural and Applied Economics 22(1340):83-99.

Akinwande, M.O., Dikko, H.G. and Samson, A. 2015. Variance inflation factor: As a condition for the inclusion of suppressor variable(s) in regression analysis. Open Journal of Statistics 5(07):754.

Arinloye, A.A.D.D., Hagelaar, J.L.F., Linnemann, A.R., Pascucci, S., Coulibaly, O., Omta, S.W.F. and van Boekel, T. 2012. Multi-governance choices by smallholder farmers in the pineapple supply chain in Benin: An application of transaction cost theory. African Journal of Business Management 38(6):10320-10331.

Bel, K.K. and Paap, R.R. 2014. A multivariate model for multinomial choices. Rasmus University Rotterdam, Netherlands.

Cappellari, L. and Jenkins, S. P. 2003. Multivariate probit regression using simulated maximum likelihood. The Stata Journal 3(3):278-294.

Fafchamps, M., and Hill, R.V. 2005. Selling at the farm gate or traveling to market American Journal of Agricultural Economics 87(3):717-734

FAO. 2014. Government of the kingdom of Lesotho support to NEPAD-CAADP implementation. http://www.fao.org/ tempref/docrep/fao/008/ae $900 \mathrm{e} /$ ae900e00.pdf. Accessed06 $6^{\text {th }}$ March 2019.

Hamilton, S.F., Richards, T.J. and Stiegert, K.W. 2013. How does advertising affectmarket performance? A note on generic advertising. Economic Inquiry 51(2):1183-1195

Hill, R.V. and Vigneri, M. 2014. Mainstreaming gender sensitivity in cash crop market supply chains. In: Gender in agriculture. Springer, Dordrecht. pp. 315-341

Jagwe, J.N. 2011. Impact of transaction costs on the participation of smallholder farmers and intermediaries in the banana markets of Burundi, Democratic Republic of Congo and Rwanda. PhD. Thesis. University of Pretoria, South Africa. 134pp.

Jari, B. and Fraser, G.C.G. 2009. An analysis of institutional and technical factors influencing agricultural marketing amongst smallholder farmers in the Kat River Valley, Eastern Cape Province, South Africa. 
African Journal of Agricultural Research 4(11):1129-1137.

Jebesa, S.R. 2019. Determinants of smallholder farmers market participation and outlet choice decision of agricultural output in Ethiopia: A review. American Journal of Agriculture and Forestry 7(4):139-145.

Key, N., Sadoulet, E. and Janvry, A. D. 2000. Transactions costs and agricultural household supply response. American Journal of Agricultural Economics 82(2):245-259.

Lancaster, N.A. and Torres, A.P. 2019. Investigating the drivers of farm diversification among us fruit and vegetable operations. Sustainability 11(12):3380.

Local Governance \& Non-state actors Support Programme (LGNSP). 2009. Information Handbook - Leribe District. Report 1. http:/ /www.pitsong. org.1s/admin/image/ LS8009603 ENC_002.pdf. Accessed 06 ${ }^{\text {th }}$ March 2019.

Maina, C.M., Lagat, K.J. and Mutai, K.B. 2015. Effect of transaction costs on choice of mango marketing channel and income of small-scale farmers in Makueni county.MSc. Thesis. Egerton University, Kenya. 62pp.

Melese, T., Goshu, D. and Tilahun, A. 2018. Determinants of outlet choices by smallholder onion farmers in Fogera district Amhara Region, Northwestern Ethiopia. Journal of Horticulture and Forestry 10(3):27-35.

Moeletsi, M.E. and Walker, S. 2013. Agroclimatological suitability mapping for dryland maize production in Lesotho. Theoretical and Applied Climatology 114(12):227-236.

Mokhtarian, P.L. and Tang, W.L. 2011. Trivariateprobit models of pre-purchase/ purchase shopping channel choice: clothing purchases in northern California, paper presented at International Choice Modelling Conference 2011, Oulton Hall (UK) 4-6 July 2011.
Mugisha, J., Bwalya, R. and Hyuha, T. 2016. Transaction costs and smallholder household access to maize markets in Zambia. Journal of Development and Agricultural Economics 8(9):328-336.

Ogada, M.J., Guthiga, P.M., Sikei, G.O., Mwabu, G., Shimba, C.O. and Momanyi, E. 2018. The burden of produce cess and other market charges in Kenya's agriculture. African Journal of Economic Review 6(2):232-245.

Okello, D. 2019. Increasing income and productivity by empowering women farmers' access to information. https:// ictupdate.cta.int/en/article/increasingincome-and-productivity-by-empoweringwomen-farmers-access-to-informationsid 08 ff 12 d 5 a -5 ba $9-47$ ce-b 1 bd a7f8aecf4f2. Accessed $13^{\text {rd }}$ November 2019.

Okoye, B.C., Abass, A., Bachwenkizi, B., Asumugha, G., Alenkhe, B., Ranaivoson, R. and Ralimanana, I. 2016. Effects of transaction costs on market participation among smallholder cassava farmers in Central Madagascar. Cogent Economics and Finance 4(1):1-21.

Osebeyo, S.O. and Aye, G.C. 2014. Transaction costs and marketing decision: a case study of smallholder tomato farmers in Makurdi, Nigeria. Urban, Planning and Transport Research 2(1):333-340

Rafoneke, L. and Rantlo, A.M. 2016. The institutional and technical constraints to peach marketing in Lesotho. International Journal of Recent Advances in Multidisciplinary Research 3(8):17951801.

Sekoai, T. and Rantlo, A. 2016. Analysis of institutional constraints to peach production in Butha-Buthe. International Journal of Information Research and Review 3(8):2647-2652.

Sigei, G., Bett, H. and Kibet, L. 2014. Determinants of market participation among smallscale pineapple farmers in 
Kericho County. MSc. Thesis. Wosene, G., Ketema, M. and Ademe, A. 2018. EgertonUniversiry. Kenya. 81pp.

Factors affecting market outlet choices of

Stock, J.H. and Watson, M.W. 2008. Heteroskedasticity robust standard errors for fixed effects panel data regression. Econometrica 76(1):155-174

Train, K.E. 2009. Discrete choice methods with simulation. Cambridge university press.New York. USA pp. 105-107.

Vorley, B. and Lançon, F. 2016. Food consumption, urbanisation and rural transformation: The trade dimensions.https: //pubs.iied.org/10767IIED/. Accessed 18 ${ }^{\text {th }}$ December 2019.

Washington, S., Karlaftis, M.G., Mannering, F. and Anastasopoulos, P. 2020. Statistical and econometric methods for transportation data analysis. CRC press. pepper producers in Wonberma district, Northwest Ethiopia: multivariate probit approach. Cogent Food \& Agriculture 4(1):1558497.

World Food Programme (WFP). 2017. Lesotho transitional interim. Country strategic plan.

Year 2018/2019. https://docs.wfp.org/api/ documents/974409e2596d4696a2b 23d5086b09e14/download/. Accessed 23 $3^{\text {rd }}$ February 2019.

Yoo, W., Mayberry, R., Bae, S., Singh, K., He, Q.P. and LillardJr, J. W. 2014. A study of effects of multicollinearity in the multivariable analysis. International Journal of Applied Science and Technology 4(5):9. 